\title{
Agrometeorological Indices and Correlation Coefficient of $B t$ Cotton Under Different Growing Environment
}

\author{
S.V. Waghmare and Madho Singh* \\ Department of Agricultural Meteorology, VNMKV, Parbhani - 431402 (MS), India \\ *Corresponding author
}

\section{Keywords \\ GDD, PTU, $B t$, \\ Cotton, Correlation. \\ Article Info \\ Accepted: \\ 07 September 2017 \\ Available Online: \\ 10 October 2017}

\section{A B S T R A C T}

A field experiment was conducted during 2012-13 at Department of Agricultural Meteorology, VNMKV, Parbhani (Maharashtra). The agrometeorological indices like GDD and PTU also showed a significant variation among different sowing dates and $B t$ hybrids of cotton. The average growing degree days were recorded among the different sowing dates was $1556^{\circ}$ days at the base temperature of $15.5^{\circ} \mathrm{C}$. The highest number of GDD (1649 ${ }^{\circ}$ days) and PTU (20249 ${ }^{\circ}$ day hrs) were accumulated in $25^{\text {th }}$ MW sowing followed by $26^{\text {th }}$ MW sowing. The lowest number of GDD (1452 ${ }^{\circ}$ days $)$ and PTU accumulation was recorded in $28^{\text {th }}$ MW (1452 ${ }^{\circ}$ days). The total number of GDD was significantly influenced by different hybrids. Among $B t$ hybrids the highest number of GDD were accumulated by Ajit- 155 and Bunny Bt ( $1561^{\circ}$ days) and the average GDD were accumulated in different hybrids was $1556{ }^{\circ}$ days. The PTU also significantly influenced by different treatments of sowing dates and different hybrids. The highest number of PTU accumulated in $25^{\text {th }}$ MW sowing followed by $26^{\text {th }}$ MW sowing. The lowest number of PTU recorded in $28^{\text {th }}$ MW sowing. Among the hybrids the highest number of PTU recorded in Ajit-155 and Bunny Bt while lowest PTU recorded in Rashi779. Correlation between weather parameter and growth stages of cotton with seed cotton yield showed that the weather parameters like rainfall, temperature, relative humidity and BSS have significant effect on critical growth stages. Rainfall during square formation and flowering stages showed positive influence on the seed cotton yield of kharif cotton. Diurnal temperature range also showed negative correlation with seed cotton yield.

\section{Introduction}

Cotton require a minimum daily temperature of $15.0^{0} \mathrm{C}\left(60{ }^{0} \mathrm{~F}\right)$ for germination, 21.0$27.0^{\circ} \mathrm{C}\left(70-80{ }^{0} \mathrm{~F}\right)$ for vegetative growth, and 27.0-32.0 $0^{\circ} \mathrm{C}\left(80-90{ }^{0} \mathrm{~F}\right)$ during the fruiting period. Mauney (1986) stated that all processes leading to square, blossom, and boll initiation, and maturation are temperature dependent. Cool nights are beneficial during the fruiting period, but extremes in temperature (low/high) can result in delayed growth and aborted fruiting sites.
Lint yield is generally reduced because of reduced boll production, primarily of fewer fruiting sites producing bolls but also because of increased fruit abscissions due to various environmental stresses. Plants with highest boll load are the most sensitive to low light intensity due to their increased requirement of photosynthate (Guinn, 1998). Cotton lint yield and fiber quality are also impacted by the amount and quality of solar radiation. Not only is lint production reduced under low 
light condition, but also the fiber produced is often of inferior quality. Water stress caused by deficiency of water, its damage as reduction in photosynthetic activity and increased in leaf senescence (Constable and Rawson, 1980).

The growth, development and yield of the crop depend on the suitability of solar radiations, temperature; humidity etc. yields are controlled by the weather parameters. Plant character which can be counted/ measured well in advance of harvest with no error or little error should be included in the forecast model. For cotton crop, plant population and number of bolls explained only 35 to 40 per cent of the variation in crop yield but with the inclusion of first picking yield as an additional explanatory variable in the model, the extent of explained variation increased to about 80 per cent. Since the first picking yield becomes available after about 4 months of sowing the crop while its final harvesting is done after 6 months, the cotton yield forecast on this basis is feasible about 2 months before harvesting.

\section{Materials and Methods}

The field Experiment was conducted during kharif season 2013-14 on experimental farm of Department of Agricultural Meteorology, College of Agriculture, Dr. Vasantrao Naik Marathawada Krishi Vidypeeth, Parbhani. Geographically Parbhani is situated at 409 MSL (Mean Sea Level), 190 16' North Latitude and 760 47' East longitude and having sub-tropical climatic condition.

The sowing was done with the help of manual labour by dibbling. The seeds of cotton hybrids namely Mallika, Ajit-155, Bunny Bt and Rashi-779 were dibbled with row to row and plant to plant spacing $(120 \times 45 \mathrm{~cm})$ during 04 different meteorological weeks 25 th MW (21-06-2013), 26th MW (28-06-2013), 27th MW (05-07-2013) and 28th MW (12-07-
2013). The daily observations on air temperature, relative humidity, precipitation and bright sunshine hours were recorded at meteorological observatory. The weather data were used for the analysis. The information about agro-meteorological indices is depending upon the climate, hybrids and soil type of the region where the crop is grown. The following agro-meteorological indices were computed using the daily meteorological data which were taken from agrometeorological observatory. The heat unit concept was initially developed to study plant- temperature relationship and to provide a method for more precisely measuring the intervals between growth stages. The daily GDD was worked out by taking the daily average temperature $(\operatorname{Tmax}+\mathrm{Tmin}) / 2$, and subtracting the base temperature from the daily average temperature. The resulting number is the number of heat units accumulated for that day. The method typically used for calculating accumulated heat units is expressed by following formula (Freeland et al., 2004).
$\mathrm{dh}$
Accumulated GDD $=\sum[(\mathrm{T} \max +\mathrm{T} \min ) / 2]-\mathrm{Tb}$ (0C day) ds

Where,

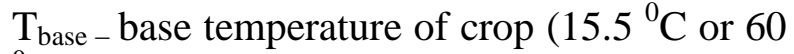
$\left.{ }^{0} \mathrm{~F}\right)$

$\mathrm{ds}=$ Date of sowing

$\mathrm{dh}=$ Date of harvest

Day and night is one of the basic factors controlling the period of vegetative growth in a photosensitive crop. The photothermal unit is the product between heat units or GDD and day length. The sum of photo thermal unit for each phenophase was worked out by using the following formula, (Kumar et al., 2012). 
Photothermal Unit $\left({ }^{0} \mathrm{C}\right.$ day $\left.\mathrm{h}\right)=\sum$ (Heat Units $\mathrm{x}$ D)

Where,

$\mathrm{D}=$ Day length in hours

The data recorded were statistically analyzed by using technique of ANOVA i.e. analysis of variance and significance was determined as given by Panse and Sukhatme (1967). The statistical analysis worked out with the help of computer.

\section{Results and Discussion}

\section{Growing degree days (degree days)}

The data given in the table 1 shows that the number of growing degree days was accumulated during the each phenophase at the base temperature of $15.5^{\circ} \mathrm{C}\left(60^{\circ} \mathrm{F}\right)$ and it was obtained $1486{ }^{\circ}$ days as general mean. The results showed that the growing degree days was significantly affected by different sowing dates and the highest number of growing degree days recorded in $25^{\text {th }} \mathrm{MW}$ $\left(1550{ }^{0}\right.$ days) followed by $26^{\text {th }}$ MW (1534 ${ }^{0}$ days) and $27^{\text {th }}$ MW sowing (1443 ${ }^{0}$ days). Whereas, the lowest number of GDD was accumulated in $28^{\text {th }}$ MW sowing $\left(1419^{0}\right.$ days $)$ It means that the daily mean temperature is more than number of GDD required less and it might be due this $25^{\text {th }} \mathrm{MW}$ sowing required more GDD and least required in $28^{\text {th }} \mathrm{MW}$. The results showed that the average number of heat units accumulated by different $\mathrm{Bt}$ hybrids during its life cycle was $1486^{0}$ days while, it was found that Ajit-155 and Bunny $B t$ recorded highest number of heat units $\left(1492^{0}\right.$ days) during its whole life cycle and the lowest number of heat units recorded in hybrid Rashi-779 (1474 ${ }^{0}$ days).

Freeland et al., (2004) reported similar results and stated that the current Bt hybrids of cotton required GDD between 1195 and 1275 degree days considering base temperature $15.5^{\circ} \mathrm{C}$. Highest GDD was recorded at boll setting to boll brusting stage $\left(\mathrm{P}_{6}\right)$ in all the hybrids with mean GDD $515^{\circ}$ days and lowest GDD recorded at flowering to boll formation stage $\left(\mathrm{P}_{5}\right)$ as the less number of days required for complete this phenophases.

\section{Photothermal unit $\left({ }^{0} \mathrm{C}\right.$ day hours).}

Photo thermal unit is the agro meteorological indices that mean how much quantity of heat energy to be used by the plant during the day. It is calculated by multiplying the daily heat units or GDD with the length of day. The no. of photo thermal units to be accumulated by the crop during its life cycle at different phenophases are given in the table 2. The photo thermal units are was influenced by the number of days required for reaching to each phenophase or to complete life cycle, daily average temperature and length of the day.

The data given in the table 2 showed the number photothermal units was accumulated during the each phenophase at the base temperature $15.5^{\circ} \mathrm{C}$ was significantly influenced by different sowing dates. The data revealed that average photothermal units accumulated during different sowing dates was observed $18880^{\circ} \mathrm{C}$ day hrs. whereas, the highest number photothermal units was recorded in $25^{\text {th }} \mathrm{MW}$ sowing $\left(20249^{\circ} \mathrm{C}\right.$ day hrs) followed by $26^{\text {th }} \mathrm{MW}$ sowing $\left(19396^{\circ} \mathrm{C}\right.$ day hrs) and $27^{\text {th }}$ MW sowing $\left(18413^{\circ} \mathrm{C}\right.$ day hrs) and the lowest in $28^{\text {th }}$ MW sowing $\left(17465^{\circ} \mathrm{C}\right.$ day hrs).

While, the highest number of PTU were recorded in $25^{\text {th }} \mathrm{MW}$ sowing at all the phenophases and the lowest in the $28^{\text {th }} \mathrm{MW}$ sowing. However, within all crop growth stages the highest number of PTU recorded at boll setting to boll brusting stage $\left(\mathrm{P}_{6}\right)$. The lowest no. of PTU was accumulated at 
flowering to boll setting $\left(\mathrm{P}_{5}\right)$ in all the sowing dates. However, amongst the different $\mathrm{Bt}$ hybrids the photothermal units were significantly influenced by different $\mathrm{Bt}$ hybrids and the mean photothermal units accumulated was observed $19001^{\circ} \mathrm{C}$ day hrs while, it was found that the highest number of photothermal unit was recorded in the Ajit155 and Bunny Bt. $\left(19392^{\circ} \mathrm{C}\right.$ day hrs $)$ and in Mallika lowest ( $18898{ }^{\circ} \mathrm{C}$ days hrs), in Rashi779 in all the sowing dates $18806^{\circ} \mathrm{C}$ day hrs.

Table.1 Phenophase wise accumulated GDD ( ${ }^{0}$ days $)$ as influenced by different treatments

\begin{tabular}{lccccccccccc}
\hline $\begin{array}{l}\text { Phenophases } \\
\text { Treatment }\end{array}$ & $\mathbf{P}_{\mathbf{1}}$ & $\mathbf{P}_{\mathbf{2}}$ & $\mathbf{P}_{\mathbf{3}}$ & $\mathbf{P}_{\mathbf{4}}$ & $\mathbf{P}_{\mathbf{5}}$ & $\mathbf{P}_{\mathbf{6}}$ & $\mathbf{P}_{\mathbf{7}}$ & $\mathbf{P}_{\mathbf{8}}$ & $\mathbf{P}_{\mathbf{9}}$ & $\mathbf{P}_{\mathbf{1 0}}$ & Mean \\
\hline $\begin{array}{l}\text { Dates of sowing } \\
25^{\text {th }} \text { MW }\end{array}$ & & & & & & & & & & & \\
$26^{\text {th }}$ MW & 84 & 260 & 86 & 176 & 48 & 528 & 186 & 86 & 80 & 65 & 1534 \\
$27^{\text {th }}$ MW & 69 & 236 & 85 & 161 & 59 & 512 & 171 & 69 & 81 & 81 & 1443 \\
$28^{\text {th }}$ MW & 55 & 243 & 88 & 168 & 62 & 498 & 144 & 59 & 102 & 33 & 1419 \\
Mean & 70 & 252 & 87 & 168 & 55 & 514 & 175 & 78 & 82 & 69 & 1486 \\
Bt hybrids & & & & & & & & & & & \\
Mallika & 71 & 255 & 87 & 167 & 56 & 517 & 174 & 78 & 83 & 63 & 1488 \\
Ajit-155 & 71 & 255 & 87 & 173 & 56 & 518 & 173 & 76 & 83 & 69 & 1492 \\
Bunny Bt & 71 & 255 & 87 & 173 & 56 & 518 & 173 & 76 & 83 & 69 & 1492 \\
Rashi-779 & 71 & 245 & 88 & 162 & 54 & 508 & 182 & 85 & 79 & 77 & 1474 \\
Mean & 71 & 252 & 87 & 168 & 55 & 515 & 175 & 78 & 82 & 69.5 & 1486 \\
\hline
\end{tabular}

Table.2 Phenophase wise accumulated photo thermal units $\left({ }^{0} \mathrm{C}\right.$ day hrs $)$ as influenced by different treatments

\begin{tabular}{lccccccccccc}
\hline $\begin{array}{l}\text { Phenophases } \\
\text { Treatment }\end{array}$ & $\mathbf{P}_{\mathbf{1}}$ & $\mathbf{P}_{\mathbf{2}}$ & $\mathbf{P}_{\mathbf{3}}$ & $\mathbf{P}_{\mathbf{4}}$ & $\mathbf{P}_{\mathbf{5}}$ & $\mathbf{P}_{\mathbf{6}}$ & $\mathbf{P}_{\mathbf{7}}$ & $\mathbf{P}_{\mathbf{8}}$ & $\mathbf{P}_{\mathbf{9}}$ & $\mathbf{P}_{\mathbf{1 0}}$ & Mean \\
\hline $\begin{array}{l}\text { Dates of sowing } \\
25^{\text {th }} \mathrm{MW}\end{array}$ & 990 & 3579 & 1188 & 2133 & 665 & 6331 & 2302 & 1145 & 737 & 1179 & 20249 \\
$26^{\text {th }} \mathrm{MW}$ & 988 & 3381 & 1108 & 2174 & 584 & 6364 & 2146 & 1011 & 846 & 794 & 19396 \\
$27^{\text {th }} \mathrm{MW}$ & 911 & 3068 & 1068 & 2008 & 734 & 6103 & 1939 & 778 & 906 & 898 & 18413 \\
$28^{\text {th }} \mathrm{MW}$ & 728 & 3125 & 1102 & 2081 & 760 & 5868 & 1627 & 665 & 1119 & 390 & 17465 \\
Mean & 904 & 3288 & 1116 & 2099 & 685 & 6166 & 2003 & 899 & 902 & 815 & 18880 \\
Bt hybrids & & & & & & & & & & & \\
Mallika & 904 & 3323 & 1113 & 2090 & 692 & 6172 & 1990 & 893 & 910 & 811 & 18898 \\
Ajit-155 & 969 & 3387 & 1113 & 2194 & 648 & 6291 & 2105 & 950 & 854 & 881 & 19392 \\
Bunny Bt & 969 & 3387 & 1113 & 2194 & 648 & 6291 & 2105 & 950 & 854 & 881 & 19392 \\
Rashi-779 & 904 & 3186 & 1126 & 1989 & 672 & 6146 & 2078 & 962 & 861 & 882 & 18806 \\
Mean & 936 & 3320 & 1116 & 2116 & 665 & 6225 & 2069 & 938 & 869 & 863 & 19122 \\
\hline
\end{tabular}


Table.3 Correlations between weather parameters and different growth stages of cotton with seed cotton yield

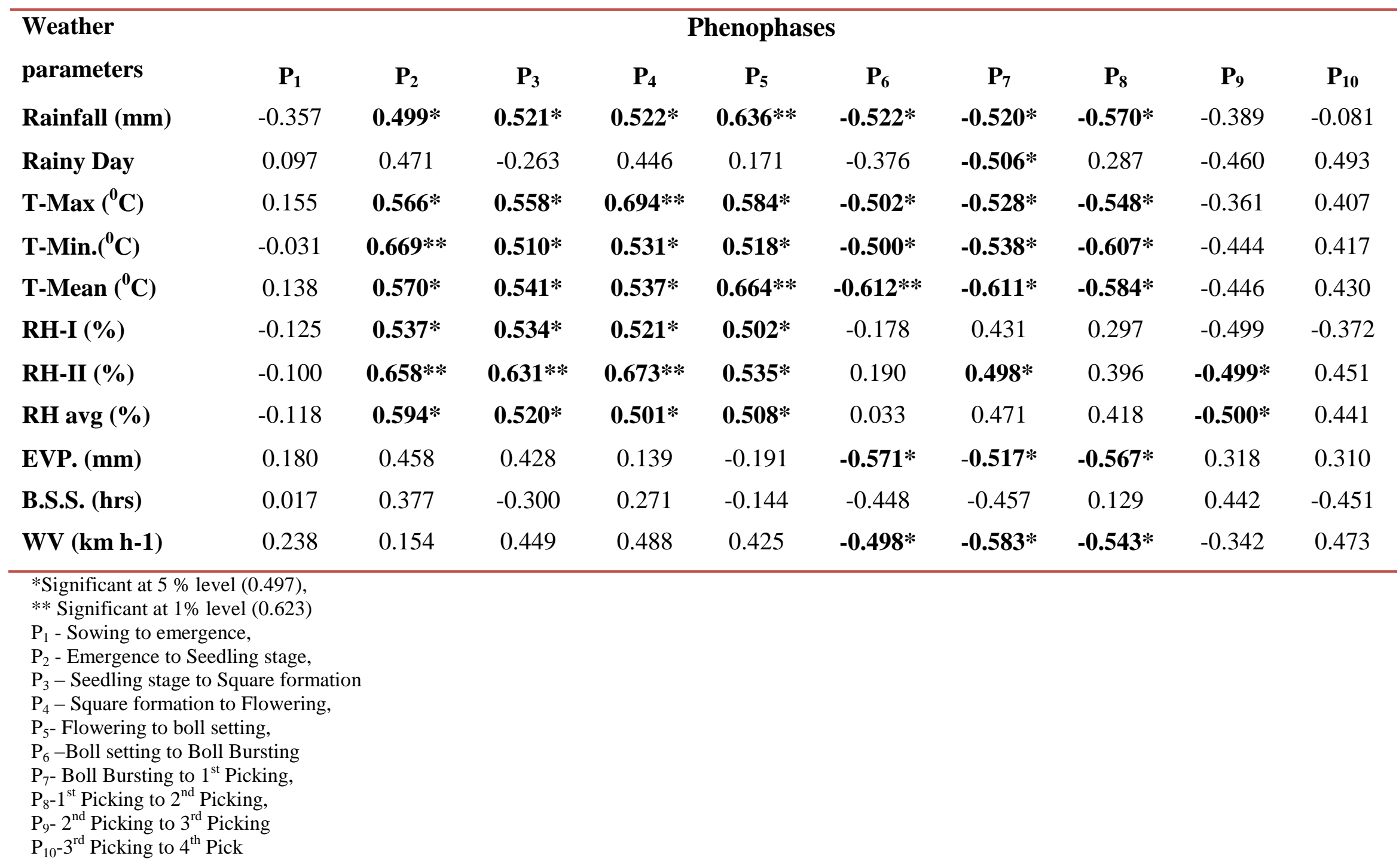




\section{Correlation studies}

The correlation study between seed cotton yield and weather parameters (abiotic factor) prevailed at different sowings and different phenophases are given in table 3 . The most critical growth stages deciding the cotton seed yield are square formation to flowering $\left(\mathrm{P}_{4}\right)$, flowering to boll setting $\left(\mathrm{P}_{5}\right)$ and boll setting to boll bursting $\left(\mathrm{P}_{6}\right)$. The data observed during the growing season of cotton crop under study period, weather parameters viz., rainfall, maximum, minimum and mean temperatures, morning relative humidity and evening relative humidity were positively correlated during early stage i.e. from seedling stage to boll setting.

While, the correlation results revealed that the weather parameters significantly influenced the on growth stages of the crop and finally reflected in to the seed yield. These weather parameters and their influence on different growth stages are illustrated below. The result revealed that the rainfall was significantly positively correlated to early growth stages i.e. seedling stage to flowering setting stage $\left(\mathrm{P}_{2}\right.$ to $\left.\mathrm{P}_{4}\right)$ and significantly negatively correlated during flowering to boll setting $\left(\mathrm{P}_{6}\right.$ to $\mathrm{P}_{8}$ ). While, it was found positively and highly significant at boll formation stage $\left(\mathrm{P}_{5}\right)$. However, the results on rainy days showed negatively significant correlation at $1^{\text {st }}$ picking stage $\left(\mathrm{P}_{7}\right)$. It means that the rainfall distribution was affecting on yield throughout the growing period of cotton and at boll brusting and harvesting negative impact was observed (Anonymous (2006). The rainfall was significant at seedling stage $\left(\mathrm{P}_{2}\right)$ and the results are inconformity with those reported by Freeland et al., (2004).The rainfall found to be statistically significant with positive direction from planting to leaf development and boll maturity phase.

Temperature also plays a major role in deciding the length of growth stages. The very high and very low temperature causes the detrimental effect on the crop growth and development. The data in table 3 revealed that the maximum, minimum and mean temperatures was positively correlated during the early growth stages i.e. from seedling stages to boll setting and significantly negatively correlated at $\mathrm{P}_{6}$ to $\mathrm{P}_{8}$ stages. However, the highly positively significant correlation was found in maximum temperature at square formation stage to flowering; in minimum temperature at emergence to seedling stage $\left(\mathrm{P}_{1}\right.$ to $\left.\mathrm{P}_{2}\right)$ as well as highly significant negative at boll setting to boll brusting stage $\left(\mathrm{P}_{5}\right.$ to $\left.\mathrm{P}_{6}\right)$.

While, morning relative humidity (RH-I) showed that the positively significant correlation at $\mathrm{P}_{2}-\mathrm{P}_{5}$ and afternoon relative humidity (RH-II) showed positively highly significant at $\mathrm{P}_{2}-\mathrm{P}_{4}$ and positively significant at $\mathrm{P}_{5}-\mathrm{P}_{7}$. However, RH-II was found negatively significant at $\mathrm{P}_{9}$. However, it was found positively significant at $\mathrm{P}_{2}-\mathrm{P}_{5}$ and negatively significant at $\mathrm{P}_{9}$ in average relative humidity (RHavg). The evening relative humidity was positively highly significant at seedling stage, boll setting to $1^{\text {st }}$ picking stage $\left(\mathrm{P}_{5}\right.$ to $\left.\mathrm{P}_{7}\right)$ and negatively significant at $3^{\text {rd }}$ picking stage $\left(\mathrm{P}_{9}\right)$. Sawan (2013) also reported that minimum relative humidity had a positive correlation with flower and boll formation. It means that the correlation analysis results revealed that the, evaporation and wind velocity negatively significant correlated at $\mathrm{P}_{6}$ to $\mathrm{P}_{9}$. The similar results were reported by Sawan (2013) revealed that the evaporation shows the negative correlation with flowering to boll brusting because of the evaporation rates could result in water stress that would slow growth and increase shedding rates of flowers and bolls.

Wind speed can also stress the cotton plant enough to reduce yield, although some wind may beneficial in very hot humid conditions. Wind modifies the temperature and humidity 
gradient around the cotton plant which in turn changes the evaporative demand. The results of analysis showed that the bright sunshine hrs was not significantly influence the crop growth stages during the crop growing period of 2013.

\section{References}

Constable, G. A., and Rawson, H. M. 1980. Effect of leaf position, expansion and age on photosynthesis, transpiration and water use efficiency of cotton. Aust. J. of Plant Physiology. 7: 89-100.

Freeland, T. B., Jr., Martin, S. M., Ebelhar, W. M. and Meredith, W. R. 2004. Yield, quality and economic impact of the 2002 harvest season rainfall in the Mississippi Delta. Pp. 600-608. Proc. Beltwide Cotton Conf., National Cotton Council, Memphis, TN.

Freeland, T.B., Pettigrew B. Jr, Thaxton P. and Andrews G. L. 2004. Agrometeorology and cotton production. Chapter 13A.
Guinn and Gene. 1998. Causes of square and boll shedding. Proc. Beltwide cotton conf., Natl. cotton council, Memphis, TN Vol 2: 1355-1364.

Kumar, N., Niwas, R. and Khichar, M.L. 2012. Performance of cotton varieties under different growing environments based on agrometeorological indices in semi-arid condition. Journal of cotton Res. Development. 26 (2): 199-201.

Mauney, J. R., 1986. Vegetative Growth and Development of Fruiting Sites. Pp. 1128. In J. R. Mauney and J. McD. Stewart (ed.) Cotton Physiology. The Cotton Foundation, Memphis.

Panse, V.G., and Sukhatme, P.V. 1978. Stastical methods for Agricultural workers. ICAR publication $3^{\text {rd }}: 157-165$.

Sawan, Z. M., 2013. Studying the relationship between climatic factors and cotton production by different applied methods. Journal of Stress Physiology \& Biochemistry, Vol. 9 No. 4, pp. 251278.

\section{How to cite this article:}

Waghmare, S.V. and Madho Singh. 2017. Agrometeorological Indices and Correlation Coefficient of Bt Cotton Under Different Growing Environment. Int.J.Curr.Microbiol.App.Sci. 6(10): 551-557. doi: https://doi.org/10.20546/ijcmas.2017.610.067 